AperTO - Archivio Istituzionale Open Access dell'Università di Torino

\title{
Chemical partitioning and antioxidant capacity of green coffee (Coffea arabica and Coffea canephora) of different geographical origin
}

\section{This is the author's manuscript}

Original Citation:

Availability:

This version is available http://hdl.handle.net/2318/1554562

since 2016-12-14T09:40:06Z

Published version:

DOI:10.1016/j.phytochem.2016.01.016

Terms of use:

Open Access

Anyone can freely access the full text of works made available as "Open Access". Works made available under a Creative Commons license can be used according to the terms and conditions of said license. Use of all other works requires consent of the right holder (author or publisher) if not exempted from copyright protection by the applicable law. 


\title{
Chemical partitioning and antioxidant capacity of green coffee (Coffea arabica and Coffea canephora) of different geographical origin
}

\author{
Oxana Babova ${ }^{\mathrm{a}}$, Andrea Occhipinti ${ }^{\mathrm{a}, \mathrm{b}}$, Massimo E. Maffei ${ }^{\mathrm{a}, \mathrm{b}, *}$
}

${ }^{a}$ Department of Life Sciences and Systems Biology, University of Turin, Via Quarello15/A, Turin, Italy

${ }^{\mathrm{b}}$ Biosfered S.r.l., Academic Spin-Off of the University of Turin, Via Quareflo 15/A,Turin, Italy

* Corresponding author: Massimo E. Maffei, Department of Life Sciences and Systems Biology, University of Turin, Via Quarello 15/A, Turin, Italy. Tel +39 011 6705967; Fax +39 0112365967.

E-mail address: massimo.maffei@unito.it 


\section{Abstract}

Green coffee beans of Coffea arabica and Coffea canephora accessions from different geographical origin (Brazil, Colombia, Ethiopia, Honduras, Kenya, Mexico, Peru, Uganda and Vietnam) were extracted and the extracts analysed by HPLC-ESI-MS/MS for the identification and quantification of chlorogenic acids and caffeine content. Principal component and cluster analyses were used to identify chemical patterns separating the different species and accessions based on their geographical origin. C. canephora showed always a higher caffeine content with respect to C. arabica, whereas the $C$. arabica accessions from Kenya showed a higher chlorogenic acids and a lower caffeine content. The antioxidant capacity of green coffee extracts was assayed by the reducing power and DPPH assays. The antioxidant capacity correlated with the chlorogenic acids content. The results show that the $C$. arabica from Kenya possesses the highest chlorogenic acids/caffeine ratio and, among the $C$. arabica accessions, the highest antioxidant capacity. Therefore, the $C$. arabica from Kenya is the most suitable green coffee source for nutraceutical applications because of its high antioxidant capacity and low caffeine content.

\section{Keywords}

Coffea arabica, Coffea canephora, Rubiaceae, Green coffee, Chlorogenic acids, Caffeine, Geographical origin, Antioxidant capacity

\section{Introduction}

Coffee is one of the major industrial products; currently grown in about 80 countries of four continents it is one of the most popular beverages in the world (Anderson and Smith, 2002; Bicho et al., 2013). The production of coffee is based on three main Coffea (Rubiaceae) species: C. arabica L. (also known as arabica coffee), C. canephora Pierre ex A. Froehner (also known as robusta coffee) and $C$. liberica Bull. ex Hiern (also knowns as Liberian or Liberica coffee, or excelsa coffee) (Davis et al., 2006). The most important commercial species is C. arabica, which provides more than $95 \%$ of the 
world's coffee (Vega et al., 2003). The chemical composition of green coffee is characterized by the presence of caffeine that can reach about $1.45 \%$ and $2.38 \%$ in C. arabica and in C. canephora, respectively (Bicho et al., 2013). Caffeine is well known as a mild stimulant of the central nervous system and the impact of caffeine on the human organism is well understood (Herman and Herman, 2013). Besides caffeine, green coffee contains high levels of phenolic compounds, with chlorogenic acids being the most abundant molecules (Clifford, 1999). Chlorogenic acids are a group of compounds comprising hydroxycinnamates, such as caffeic acid, ferulic acid, and p-coumaric acid, linked to quinic acid to form a range of conjugated structures known as caffeoylquinic acids, feruloylquinic acids, and $p$-coumaroylquinic acids all of which exist in several isomeric forms (Baeza et al., 2014; Clifford, 1999; Clifford and Knight, 2004; Del Rio et al,, 2010; Ky et al., 2013).

Despite the controversial effects of caffeine and other compounds present in the roasted coffee, green coffee beans utilization is gaining an increasing interest in the nutraceutical and pharmaceutical industry because they are accepted as a rich source of compounds possessing antioxidant and radical scavenging activities (Anissi et al., 2014; Bresciani et al., 2014; Brezova et al., 2009 and references cited therein). Chlorogenic acids are the major contributors to the antioxidant properties of green coffee (Abrahao et al., 2010; Farah et al., 2006; Lima et al., 2010). On the other hand, a high content of caffeine lowers the applicability of green coffee extracts to prepare dietary supplements to be used as antioxidants, owing to the its known effects on the nervous system. Therefore, the market requires the identification of $C$. arabica and $C$. canephora accession with a high chlorogenic acid/caffeine ratio. The aim of our this study was the chemical characterization of several $C$. arabica and $C$. canephora accessions of green coffee from different geographic origin in order to identify specific chemical patterns and antioxidant capacity that may be suitable for nutraceutical and pharmaceutical applications.

\section{Results and discussion}


2.1. Total hydroxycinnamic acid derivatives and caffeine determination in Coffea canephora and Coffea arabica

The chemical composition of green coffee from different geographical origins is characterized by the presence of several chlorogenic acids, including esters of trans-cinnamic acids and quinic acid (Table 1). Caffeic acid (1), $p$-coumaroyl quinic acid (2), $p$-coumaroyl- $N$-tryptophan (3), chlorogenic acid (3$O$-caffeoylquinic acid (4), neochlorogenic acid (5-O-caffeoylquinic acid, 5), cryptochlorogenic acid (4-O-caffeoylquinic acid, 6), caffeoyl- $N$-tryptophan (7), 3-O-feruloylquinic acid (8), 5-Oferuloylquinic acid (9), 3,4-O-dicaffeoylquinic acid (10), 3,5-O-dicaffeoylquinic acid (11), 4,5-Odicaffeoylquinic acid (12), 3-O-feruloyl-4-caffeoylquinic acid (13), 3-O-feruloyl-5-caffeoylquinic acid (14), 4- $O$-feruloyl-5-caffeoylquinic acid (15), and caffeine (16) were isolated (Figure 1), as is typical of the $C$. arabica and C. canephora species (Alonso-Salces et al., 2009; Clifford, 1999; Clifford and Knight, 2004; Del Rio et al., 2010). Among phenolic compounds, neochlorogenic acid (5) was the most abundant compound in all samples analyzed, followed by chlorogenic acid (4) (Table 1). Caffeine (16) was the second most abundant compound in all analyzed samples (Table 1).

The total amount of identified compounds shows a clear and significant distinction between $C$. canephora from Uganda and Vietnam and all other $C$. arabica accessions. Among the latter, $C$. arabica from Ethiopia showed the lowest amount (Figure 2). These data are in agreement with the literature data, confirming a higher content of chlorogenic acids and caffeine in the C. canephora accessions (Alonso-Salces et al., 2009; Correia et al., 1995; Guerrero and Suarez, 2001).

One of the crucial parameters for the use of green coffee in dietary supplements is the ratio between caffeine and total chlorogenic acids, the latter being responsible for most of the antioxidant capacity of green coffee extracts. Moreover, concentrations of phenolic compounds and methylxanthines are considered reliable geographical indicators, as well as chemotaxonomical markers (Alonso-Salces et al., 2009). The plot of caffeine against total chlorogenic acids shows a clear distinction between $C$. canephora accessions from Uganda and Vietnam and all the other C. arabica accessions (Figure 3). 
In particular, C. canephora (robusta) shows high levels of both caffeine and total chlorogenic acids, which agrees with the highest total content of extracted compounds (Figure 2). With the sole exception for Honduras accessions, a clear separation was found among C. arabica accessions according to their geographical origin, with a narrow differentiation based on caffeine and a broad differentiation based on their content of total chlorogenic acids (Figure 3). In particular, the accessions from Ethiopia and Mexico show the lowest content of both caffeine and chlorogenic acids, whereas the accessions from Kenya have a relatively low caffeine content and the highest content of chlorogenic acids (Figure 3).

\subsection{Principal component analysis and cluster analyses of $\mathrm{C}$. arabica and $\mathrm{C}$. canephora accessions}

Different classes of compounds have been used for the authentication of different coffee varieties (Alonso-Salces et al., 2009 and references cited therein) and for distinguishing the species and origins of green coffee bean samples of $C$. arabica and $C$. canephora from different geographic regions (Rodrigues et al., 2009; Sberveglieri et al., 2011; Serra et al., 2005; Wei et al., 2012). We used the data set of Table 1 to calculate a Principal Component Analysis (PCA). Figure 4 shows the scatter plot of the two main PCA factor loadings, which explained the $96 \%$ and $3 \%$ of the total variance for Factor 1 and Factor 2, respectively. A discrimination between the C. canephora accessions and all other C. arabica species was observed, mainly because of Factor 2 scores (negative for C. canephora and positive for $C$. arabica). Among C. arabica, a separation was found for C. arabica from Kenya and all other accessions, which were separated by positive values of Factor 1. A separation was also observed for the "caracol" accession from Brasil (C-Brasil). The "caracol” (or "snail” in Spanish, also called peaberry) is a natural mutation of the $C$. canephora coffee bean inside its cherry that affects about $5 \%$ of the world coffee. The phenotype of these "caracol" green coffee produces a single, rather than a double bean that appears smaller, denser and with a more rounded shape with respect to 
the wild type (Cilas and Bouharmont, 2005; Giomo et al., 2008). As expected, the chemical pattern of the C-Brasil accession places it closer to the C. canephora group (Figure 4).

A Cluster Analysis (CA) calculated on the data matrix of Table 1, by using Euclidean distance with median linkage method, shows a first cluster that isolates the A-Kenya accessions because of the higher content of neochlorogenic acid (5). A second cluster is made by all C. canephora accessions, with a close statistical linkage between R-Vietnam1 and R-Vietnam2. This cluster is generated because of the high amount of caffeine (16). A third cluster isolates the C-Brasil accession because of the presence of 4-O-feruloyl-5-caffeoylquinic acid (15), whereas a fourth cluster gathers the APeru1 accession containing a higher content of caffeic acid (1). All other C. arabica accessions are present in the last cluster because of the high amount of chlorogenic acids. Several subclusters compose this last cluster (see Supplementary Figure S1).

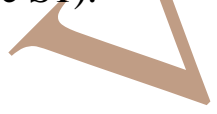

\subsection{In Vitro Antioxidant capacity of $\mathrm{C}$. arabica and C. canephora}

In order to assess the antioxidant capacity of the green coffee extracts, we evaluated their reducing power by ferric thiocyanate assay and the free radical scavenging activities by DPPH radical assay. In general, the extracts were more active as antioxidants when tested by the reducing power assay (Figure 5), since the steric accessibility of DPPH nitrogen-centered radical strongly affects the reaction rate of antioxidant compounds (Prior et al., 2005). Figure 5 depicts the scatter plot of IC $_{50}$ values from both tests. As expected, the four C. canephora accessions showed the highest antioxidant activity (lowest $\mathrm{IC}_{50}$ values for both assays) with respect to all other accessions. Although weaker than chlorogenic acid (Zhao et al., 2015), caffeine as well possesses antioxidant capacity, as recently demonstrated in in vivo experiments (Tsoi et al., 2015). Therefore, the higher content of both chlorogenic acids and caffeine correlates with a higher antioxidant capacity.

Among the $C$. arabica accessions, the samples from Kenya showed the highest antioxidant capacity, followed by one of the accessions from Peru (A-Peru2) and one from Honduras (A-Honduras2). The 
lowest antioxidant capacity was observed in the Ethiopian (A-Ethiopia) and Guatemala (AGuatemala) accessions, whereas intermediate antioxidant activities were observed for the remaining green coffee accessions.

\section{Concluding remarks}

Green coffee is a natural source of antioxidants, with chlorogenic acids being the most active compounds. We confirmed that analysis of chlorogenic acids, along with the caffeine content, is a powerful tool for the chemical partition between C. arabica (arabica) and C.canephora (robusta). Our preliminary study indicates the possibility to extend this analysis for the identification of different green coffee accessions also at the geographical level, which could be indicative for further works using the approach here presented. However, to better assess the geographical origin and not only the species effect, more samples from different countries and from the same species should be evaluated. Finally, the antioxidant capacity of green coffee was found to correlate with the content of chlorogenic acids and we identified in the $C$. arabica from Kenya the best source of high chlorogenic and low caffeine content. Therefore, the Kenya accessions of $C$. arabica can be considered an optimal source of green coffee for nutraceutical and pharmaceutical applications.

\section{Experimental}

\subsection{Plant material}

Coffea arabica L.and C. canephora Pierre ex A. Froehner (Rubiaceae) green coffee beans were kindly provided by Green Elite Coffee (Genova - Italy). Table 2 summarized the species, cultivars and the place of origin of the different green coffee accessions.

\subsection{Extraction of green coffee compounds}


Green coffee beans were ground with a blender and passed through a coarse sieve with $2 \mathrm{~mm}$ diameter holes. Ten grams of ground material were extracted with $50 \mathrm{ml}$ of a $50 \% \mathrm{v} / \mathrm{v}$ ethanol:water solution by maceration in the dark for 7 days, by shaking samples twice a day. This period of maceration was selected after several trials from 3 to 14 days because of a better extraction and reproducibility. Kinetics of extraction showed no qualitative variations between 1 to 7 days of maceration (data not shown). The extract was then filtered and stored at $4{ }^{\circ} \mathrm{C}$ until chemical analysis.

\subsection{Isolation and chemical characterization of green coffee phenolics and caffeine}

The characterization of chlorogenic acids and caffeine was performed according to Campa et al. (2005) and Alonso-Salces et al. (2009) with some modifications. Green coffee extracts were analysed by high performance liquid chromatography (1200 HPLC, Agilent Technologies, USA) equipped with a C18 $(2.6 \mu \mathrm{m}, 100 \times 3.0 \mathrm{~mm})$ Kinetex (Phenomenex, USA) reverse phase column. The solvent system was: A) MilliQ $\mathrm{H}_{2} \mathrm{O}$ (Millipore, U.S.A.) with $0.1 \% \mathrm{v} / \mathrm{v}$ of formic acid and B), acetonitrile (Panreac, Spain) with $0.1 \% \mathrm{v} / \mathrm{v}$ of formic acid. The separation was performed at a constant flow rate $\left(200 \mu 1 \mathrm{~min}^{-1}\right.$ ) with the following conditions: linear gradient from $3 \%$ to $15 \%$ of $\mathrm{B}$ in $10 \mathrm{~min}$, from $15 \%$ to $55 \%$ in $25 \mathrm{~min}$, from $55 \%$ to $98 \%$ in $3 \mathrm{~min}$, then isocratic elution for $5 \mathrm{~min}$ and a linear gradient from $98 \%$ to $3 \%$ in 4 min. Tandem mass spectrometry analyses were performed with a 6330 Series Ion Trap LC-MS System (Agilent Technologies, U.S.A.) equipped with an electrospray ionization source (ESI) operating in negative mode for the determination of phenolic compounds and in positive mode for caffeine analysis. Supplementary Table $S 1$ lists the $m / z$ and mass fragmentation data of all jdentified compounds. Qualitative analyses were performed in scan mode $(50-800 \mathrm{~m} / \mathrm{z})$ while quantitative analyses were performed in Multiple Reaction Monitoring (MRM). For quantitative determinations, calibration curves were built with caffeic acid $\left(\mathrm{R}^{2}=0.996\right)$, chlorogenic acid $\left(\mathrm{R}^{2}=0.996\right)$ and caffeine $\left(\mathrm{R}^{2}=0.998\right)$ (Sigma-Aldrich, USA). 
The reducing power assay was performed by mixing a proper dilution of samples (100 $\mu \mathrm{l})$ with 250 $\mu 1$ of phosphate buffer $(0.2 \mathrm{M}, \mathrm{pH} 6.6)$ and $250 \mu \mathrm{l}$ of $1 \% \mathrm{w} / \mathrm{v}$ potassium ferricyanide (Capuzzo et al., 2014; Oyaizu, 1986). The mixture was incubated at $50^{\circ} \mathrm{C}$ for $20 \mathrm{~min}$. At the end of incubation, 250 $\mu \mathrm{l}$ of $10 \% \mathrm{w} / \mathrm{v}$ of trichloracetic acid were added and the mixture and centrifuged at $1000 \mathrm{~g}$ for $2 \mathrm{~min}$. The supernatant $(500 \mu \mathrm{l})$ was mixed with distilled water $(500 \mu \mathrm{l})$ and $0.1 \% \mathrm{w} / \mathrm{v}$ iron (III) chloride (100 $\mu \mathrm{l})$. The absorbance was measured at $700 \mathrm{~nm}$ against a blank sample.

The free radical scavenging activity was measured using 1,1-diphenyl-2-picryl-hydrazil stable radical (DPPH•), based on the method described by Vladimir-Knezevic and co-workers (2011). Briefly, 500 $\mu 1 \mathrm{DPPH}$ working solution $(0.1 \mathrm{mM}$ in $95 \% \mathrm{v} / \mathrm{v}$ ethanol) were added to different volumes $(10-500$ $\mu 1)$ of diluted samples $(50 \% \mathrm{v} / \mathrm{v}$ ethanol). The reaction mixture was left to stand for $30 \mathrm{~min}$ in the dark at room temperature and periodically shaken. The absorbance was measured at $517 \mathrm{~nm}$ against a blank sample. For each extract, the antioxidant activity of samples was calculated using the following equation:

$\%=\left[\left(\mathrm{A}_{\text {blank }}-\mathrm{A}_{\text {sample }}\right) / \mathrm{A}_{\text {blank }}\right] * 100$

where $A_{\text {blank }}$ is the absorbance of blank, and $A_{\text {sample }}$ the absorbance of sample at $517 \mathrm{~nm}$.

$\mathrm{IC}_{50}$ values were determined from the plot of scavenging activity against the compounds concentrations, which were defined as the total antioxidant necessary to decrease the initial DPPH radical concentration by $50 \%$.

\subsection{Statistical analyses}

The overall data sets is expressed as mean values of at least three biological replicates. Three technical replicates were run for each biological replicate (i.e., 3 sub-samples were taken from one sample for analysis as triplicate analysis, and each of sub-samples was then measured 3 times during instrumental analysis). ANOVA and Tukey-Kramer's HSD test $(\mathrm{P}<0.05)$ were used to determine significant differences among extractions and compounds. Principal component analysis was performed using covariant matrix of extraction and varimax rotation. Cluster analysis was calculated by using 
Euclidean distance with median linkage method. All statistical analyses were performed by using the SYSTAT 10 software.

\section{Acknowledgements}

This work was supported by a grant from the PhD School of Pharmaceutical and Biomolecular

Sciences of the University of Turin. The authors wish to thank Mr. Elio Vercelli, Green Elite Coffee S.R.L., Genova, Italy, for kindly providing the green coffee accessions.

\section{Appendix A. Supplementary data}

Supplementary data associated with this article can be found, in the online version, at:.... These data include mass spectrometry data of the identified compounds and the cluster analysis of the most important compounds described in this article.

\section{References}

Abrahao, S. A., Pereira, R., Duarte, S. M. D., Lima, A. R., Alvarenga, D. J., Ferreira, E. B., 2010. Coffee (Coffea arabica L.) bioactive compounds and antioxidant activity. Cienc. Agrotec. 34, 414-420.

Alonso-Salces, R. M., Serra, F., Reniero, F., Heberger, K., 2009. Botanical and Geographical Characterization of Green Coffee (Coffea arabica and Coffea canephora): Chemometric Evaluation of Phenolic and Methylxanthine Contents. J. Agr. Food Chem. 57, 4224-4235.

Anderson, K. A., Smith, B. W., 2002. Chemical profiling to differentiate geographic growing origins of coffee. J. Agr. Food Chem. 50, 2068-2075.

Anissi, J., El Hassouni, M., Ouardaoui, A., Sendide, K., 2014. A comparative study of the antioxidant scavenging activity of green tea, black tea and coffee extracts: A kinetic approach. Food Chem. $150,438-447$. 
Baeza, G., Amigo-Benavent, M., Sarria, B., Goya, L., Mateos, R., Bravo, L., 2014. Green coffee hydroxycinnamic acids but not caffeine protect human HepG2 cells against oxidative stress. Food Res. Int. 62, 1038-1046.

Bicho, N. C., Lidon, F. C., Ramalho, J. C., Leitao, A. E., 2013. Quality assessment of Arabica and Robusta green and roasted coffees - A review. Emir. J. Food Agr. 25, 945-950.

Bresciani, L., Calani, L., Bruni, R., Brighenti, F., Del Rio, D., 2014. Phenolic composition, caffeine content and antioxidant capacity of coffee silverskin. Food Res. Int. 61, 196-201.

Brezova, V., Slebodova, A., Stasko, A., 2009. Coffee as a source of antioxidants: An EPR study. Food Chem. 114, 859-868.

Campa, C., Doulbeau, S., Dussert, S., Hamon, S., Noirot, M., 2005. Qualitative relationship between caffeine and chlorogenic acid contents among wild Coffea species. Food Chem. 93, 135-139.

Capuzzo, A., Occhipinti, A., Maffei, M. E., 2014. Antioxidant and radical scavenging activities of chamazulene. Nat. Prod. Res. 28, 2321-2323.

Cilas, C., Bouharmont, P., 2005. Genetic studies on several bean traits of Coffea canephora coffee in Cameroon. J. Sci. Food Agr. 85, 2369-2374.

Clifford, M. N., 1999. Chlorogenic acids and other cinnamates - nature, occurrence and dietary burden. J. Sci. Food Agr. 79, 362-372.

Clifford, M. N., Knight, S., 2004. The cinnamoyl-amino acid conjugates of green robusta coffee beans. Food Chem. 87, 457-463.

Correia, A., Leitao, M. C. A., Clifford, M. N., 1995. Caffeoyl-tyrosine and Angola-II as characteristic markers for angolan robusta coffee. Food Chem. 53, 309-313.

Davis, A. P., Govaerts, R., Bridson, D. M., Stoffelen, P., 2006. An annotated taxonomic conspectus of the genus Coffea (Rubiaceae). Bot. J. Linn. Soc. 152, 465-512.

Del Rio, D., Stalmach, A., Calani, L., Crozier, A., 2010. Bioavailability of Coffee Chlorogenic Acids and Green Tea Flavan-3-ols. Nutrients 2, 820-833. 
Farah, A., De Paulis, T., Moreira, D. P., Trugo, L. C., Martin, P. R., 2006. Chlorogenic acids and lactones in regular and water-decaffeinated arabica coffees. J. Agr. Food Chem. 54, 374-381.

Giomo, G. S., Nakagawa, J., Gallo, P. B., 2008. Beneficiamento de sementes de café e efeitos na qualidade física. Bragantia 67, 997-1010.

Guerrero, G., Suarez, M., 2001. Chlorogenic acids as a potential criterion in coffee genotype selections. J. Agr. Food Chem. 49, 2454-2458.

Herman, A., Herman, A. P., 2013. Caffeine's Mechanisms of Action and Its Cosmetic Use. Skin Pharmacol. Physiol. 26, 8-14.

Ky, C. L., Barre, P., Noirot, M., 2013. Genetic investigations on the caffeine and chlorogenic acid relationship in an interspecific cross between Coffea liberica dewevrei and $C$. pseudozanguebariae. Tree Genet. Genomes 9, 1043-1049.

Lima, A. R., Pereira, R. G. F. A., Abrahao, S. A., Duarte, S. M. D., Paula, F. B. D., 2010. Coffee Bioactive Compounds: In Vitro Antioxidant Activity of Green and Roasted Coffees before and after Decaffeination. Quim Nova 33,20-24.

Oyaizu, M., 1986. Studies on products of browning reaction. Antioxidative activities of products of browning reaction prepared from glucosamine. Jap. J. Nutrit. Dietet. 44, 9.

Prior, R. L., Wu, X. L., Schaich, K., 2005. Standardized methods for the determination of antioxidant capacity and phenolics in foods and dietary supplements. J. Agr. Food Chem. 53, 4290-4302.

Rodrigues, C. I., Maia, R., Miranda, M., Ribeirinho, M., Nogueira, J. M. F., Maguas, C., 2009. Stable isotope analysis for green coffee bean: A possible method for geographic origin discrimination. J. Food Compos. Anal. 22, 463-471.

Sberveglieri, V., Concina, I., Falasconi, M., Ongo, E., Pulvirenti, A., Fava, P., 2011. Identification Of Geographical Origin Of Coffee Before And After Roasting By Electronic Noses. In: Gouma, P. (Ed.), Olfaction and Electronic Nose: Proceedings of the 14th International Symposium on Olfaction and Electronic Nose, vol. 1362. Amer. Inst. Physics, Melville, pp. 86-87. 
Serra, F., Guillou, C. G., Reniero, F., Ballarin, L., Cantagallo, M. I., Wieser, M., Iyer, S. S., Heberger, K., Vanhaecke, F., 2005. Determination of the geographical origin of green coffee by principal component analysis of carbon, nitrogen and boron stable isotope ratios. Rapid Commun. Mass Sp. 19, 2111-2115.

Tsoi, B., Yi, R. N., Cao, L. F., Li, S. B., Tan, R. R., Chen, M., Li, X. X., Wang, C., Li, Y. F., Kurihara, H., He, R. R., 2015. Comparing antioxidant capacity of purine alkaloids: A new, efficient trio for screening and discovering potential antioxidants in vitro and in vivo. Food Chem. 176, 411419.

Vega, F. E., Rosenquist, E., Collins, W., 2003. Global project needed to tackle coffee crisis. Nature 425, 343-343.

Vladimir-Knezevic, S., Blazekovic, B., Stefan, M. B., Alegro, A., Koszegi, T., Petrik, J., 2011. Antioxidant Activities and Polyphenolic Contents of Three Selected Micromeria Species from Croatia. Molecules 16, 1454-1470.

Wei, F. F., Furihata, K., Koda, M., Hu, F. Y., Kato, R., Miyakawa, T., Tanokura, M., 2012. C-13 NMR-Based Metabolomics for the Classification of Green Coffee Beans According to Variety and Origin. J. Agr. Food Chem. 60, 10118-10125.

Zhao, E. H., Ergul, B., Zhao, W., 2015. Caffeine's Antioxidant Potency Optically Sensed with Double-Stranded DNA-Encased Single-Walled Carbon Nanotubes. J. Phys. Chem. B 119, 4068-4075. 
Table 1. Chemical composition of green coffee beans. Values are expressed as $\mathrm{g} \mathrm{kg}^{-1}$ dry wt. (Standard Deviation).

\begin{tabular}{|c|c|c|c|c|c|c|c|c|c|c|c|c|c|c|c|c|}
\hline \multirow[t]{2}{*}{ Code name } & \multicolumn{16}{|c|}{ Compounds } \\
\hline & 1 & 2 & 3 & 4 & 5 & 6 & 7 & 8 & 9 & 10 & & 12 & 13 & 14 & 15 & 16 \\
\hline A-Brasil & $\begin{array}{l}0.02 \\
(0.01)\end{array}$ & $\begin{array}{l}0.16 \\
(0.01)\end{array}$ & $\begin{array}{l}0.01 \\
(0.001)\end{array}$ & $\begin{array}{l}0.37 \\
(0.03)\end{array}$ & $\begin{array}{l}1.73 \\
(0.33)\end{array}$ & $\operatorname{tr}$ & $\begin{array}{l}0.04 \\
(0.002)\end{array}$ & $\begin{array}{l}0.01 \\
(0.002)\end{array}$ & $\begin{array}{l}0.09 \\
(0.03)\end{array}$ & $\begin{array}{l}0.05 \\
(0.01)\end{array}$ & $\begin{array}{l}0.09 \\
(0.03)\end{array}$ & $\begin{array}{l}0.09 \\
(0.02)\end{array}$ & $\operatorname{tr}$ & $\operatorname{tr}$ & $\begin{array}{l}0.01 \\
(0.001)\end{array}$ & $\begin{array}{l}1.20 \\
(0.10)\end{array}$ \\
\hline A-Colombia & $\begin{array}{l}0.01 \\
(0.004)\end{array}$ & $\begin{array}{l}0.14 \\
(0.01)\end{array}$ & $\begin{array}{l}0.01 \\
(0.001)\end{array}$ & $\begin{array}{l}0.37 \\
(0.05)\end{array}$ & $\begin{array}{l}1.68 \\
(0.43)\end{array}$ & $\operatorname{tr}$ & $\begin{array}{l}0.07 \\
(0.004)\end{array}$ & $\begin{array}{l}0.01 \\
(0.003\end{array}$ & $\begin{array}{l}0.11 \\
(0.05)\end{array}$ & $\begin{array}{l}0.04 \\
(0.01)\end{array}$ & $\begin{array}{l}0.11 \\
(0.02)\end{array}$ & $\begin{array}{l}0.09 \\
(0.02)\end{array}$ & $\operatorname{tr}$ & $\begin{array}{l}0.01 \\
(0.002)\end{array}$ & $\begin{array}{l}0.01 \\
(0.001)\end{array}$ & $\begin{array}{l}1.03 \\
(0.03)\end{array}$ \\
\hline A-Ethiopia & $\operatorname{tr}$ & $\begin{array}{l}0.11 \\
(0.01)\end{array}$ & $\operatorname{tr}$ & $\begin{array}{l}0.19 \\
(0.04)\end{array}$ & $\begin{array}{l}1.56 \\
(0.13)\end{array}$ & $\begin{array}{l}0.02 \\
(0.03)\end{array}$ & $\begin{array}{l}0.03 \\
(0.003)\end{array}$ & $\operatorname{tr}$ & $\begin{array}{l}0.07 \\
(0.02)\end{array}$ & $\begin{array}{l}0.02 \\
(0.004)\end{array}$ & $\begin{array}{l}0.13 \\
(0.02)\end{array}$ & $\begin{array}{l}0.04 \\
(0.01)\end{array}$ & $\operatorname{tr}$ & $\operatorname{tr}$ & $\operatorname{tr}$ & $\begin{array}{l}0.92 \\
(0.11)\end{array}$ \\
\hline A-Guatemala & $\begin{array}{l}0.01 \\
(0.003)\end{array}$ & $\begin{array}{l}0.14 \\
(0.02)\end{array}$ & $\begin{array}{l}0.01 \\
(0.001)\end{array}$ & $\begin{array}{l}0.36 \\
(0.12)\end{array}$ & $\begin{array}{l}1.65 \\
(0.33)\end{array}$ & $\begin{array}{l}0.02 \\
(0.03)\end{array}$ & & $(0.003)$ & $\begin{array}{l}0.08 \\
(0.02)\end{array}$ & $\begin{array}{l}0.04 \\
(0.01)\end{array}$ & $\begin{array}{l}0.08 \\
(0.02)\end{array}$ & $\begin{array}{l}0.07 \\
(0.01)\end{array}$ & $\operatorname{tr}$ & $\operatorname{tr}$ & $\operatorname{tr}$ & $\begin{array}{l}1.00 \\
(0.02)\end{array}$ \\
\hline A-Honduras1 & $\begin{array}{l}0.02 \\
(0.003)\end{array}$ & $\begin{array}{l}0.11 \\
(0.02)\end{array}$ & $\operatorname{tr}$ & $\begin{array}{l}0.32 \\
(0.08)\end{array}$ & $\begin{array}{l}1.54 \\
(0.09)\end{array}$ & $(0.02)$ & $(0.01)$ & $\begin{array}{l}0.01 \\
(0.001)\end{array}$ & $\begin{array}{l}0.08 \\
(0.03)\end{array}$ & $\begin{array}{l}0.03 \\
(0.01)\end{array}$ & $\begin{array}{l}0.06 \\
(0.001)\end{array}$ & $\begin{array}{l}0.08 \\
(0.01)\end{array}$ & $\operatorname{tr}$ & $\operatorname{tr}$ & $\operatorname{tr}$ & $\begin{array}{l}1.02 \\
(0.09)\end{array}$ \\
\hline A-Honduras2 & $\begin{array}{l}0.03 \\
(0.01)\end{array}$ & $\begin{array}{l}0.14 \\
(0.01)\end{array}$ & $\begin{array}{l}0.01 \\
(0.001)\end{array}$ & $\begin{array}{l}0.45 \\
(0.08)\end{array}$ & 1.79 & $\begin{array}{l}0.02 \\
(0.03)\end{array}$ & $\begin{array}{l}0.07 \\
(0.002)\end{array}$ & $\begin{array}{l}0.01 \\
(0.003)\end{array}$ & $\begin{array}{l}0.09 \\
(0.03)\end{array}$ & $\begin{array}{l}0.05 \\
(0.02)\end{array}$ & $\begin{array}{l}0.08 \\
(0.01)\end{array}$ & $\begin{array}{l}0.09 \\
(0.03)\end{array}$ & $\operatorname{tr}$ & $\operatorname{tr}$ & $\begin{array}{l}0.01 \\
(0.003)\end{array}$ & $\begin{array}{l}1.08 \\
(0.07)\end{array}$ \\
\hline A-Honduras3 & $\begin{array}{l}0.01 \\
(0.01)\end{array}$ & $\begin{array}{l}0.13 \\
(0.02)\end{array}$ & $\begin{array}{l}0.01 \\
(0.001)\end{array}$ & 0.27 & $\begin{array}{l}1.56 \\
(0.32)\end{array}$ & $\begin{array}{l}0.04 \\
(0.04)\end{array}$ & $\begin{array}{l}0.05 \\
(0.003)\end{array}$ & $\begin{array}{l}0.01 \\
(0.002)\end{array}$ & $\begin{array}{l}0.10 \\
(0.03)\end{array}$ & $\begin{array}{l}0.03 \\
(0.01)\end{array}$ & $\begin{array}{l}0.11 \\
(0.03)\end{array}$ & $\begin{array}{l}0.08 \\
(0.02)\end{array}$ & $\operatorname{tr}$ & $\begin{array}{l}0.01 \\
(0.001)\end{array}$ & $\operatorname{tr}$ & $\begin{array}{l}1.09 \\
(0.03)\end{array}$ \\
\hline
\end{tabular}




\begin{tabular}{|c|c|c|c|c|c|c|c|c|c|c|c|c|c|c|c|c|}
\hline \multirow[t]{2}{*}{ Code name } & \multicolumn{16}{|c|}{ Compounds } \\
\hline & 1 & 2 & 3 & 4 & 5 & 6 & 7 & 8 & 9 & 10 & 11 & 12 & & 14 & 15 & 16 \\
\hline A-Honduras4 & $\begin{array}{l}0.03 \\
(0.01)\end{array}$ & $\begin{array}{l}0.13 \\
(0.01)\end{array}$ & $\begin{array}{l}0.01 \\
(0.001)\end{array}$ & $\begin{array}{l}0.40 \\
(0.04)\end{array}$ & $\begin{array}{l}1.72 \\
(0.23)\end{array}$ & $\begin{array}{l}0.06 \\
(0.002)\end{array}$ & $\begin{array}{l}0.07 \\
(0.02)\end{array}$ & $\begin{array}{l}0.01 \\
(0.003)\end{array}$ & $\begin{array}{l}0.11 \\
(0.06)\end{array}$ & $\begin{array}{l}0.05 \\
(0.01)\end{array}$ & $\begin{array}{l}0.09 \\
(0.01)\end{array}$ & 0.10 & & $\operatorname{tr}$ & $\begin{array}{l}0.01 \\
(0.001)\end{array}$ & $\begin{array}{l}1.06 \\
(0.06)\end{array}$ \\
\hline A-Honduras5 & $\begin{array}{l}0.03 \\
(0.004)\end{array}$ & $\begin{array}{l}0.12 \\
(0.01)\end{array}$ & $\begin{array}{l}0.01 \\
(0.002)\end{array}$ & $\begin{array}{l}0.37 \\
(0.04)\end{array}$ & $\begin{array}{l}1.81 \\
(0.16)\end{array}$ & $\begin{array}{l}0.06 \\
(0.001)\end{array}$ & $\begin{array}{l}0.07 \\
(0.06)\end{array}$ & $\begin{array}{l}0.01 \\
(0.003)\end{array}$ & $\begin{array}{l}0.11 \\
(0.05)\end{array}$ & $\begin{array}{l}0.04 \\
(0.002)\end{array}$ & & $\begin{array}{l}0.12 \\
(0.03)\end{array}$ & $\operatorname{tr}$ & $\operatorname{tr}$ & $\begin{array}{l}0.01 \\
(0.001)\end{array}$ & $\begin{array}{l}1.01 \\
(0.03)\end{array}$ \\
\hline A-Kenia1 & $\begin{array}{l}0.06 \\
(0.003)\end{array}$ & $\begin{array}{l}0.18 \\
(0.017)\end{array}$ & $\operatorname{tr}$ & $\begin{array}{l}0.45 \\
(0.04)\end{array}$ & $\begin{array}{l}1.96 \\
(0.26)\end{array}$ & $\begin{array}{l}0.06 \\
(0.03)\end{array}$ & $\begin{array}{l}0.03 \\
(0.004)\end{array}$ & $\begin{array}{l}0.01 \\
(0.01)\end{array}$ & $\begin{array}{l}0.13 \\
(0.07)\end{array}$ & $\begin{array}{l}0.05 \\
(0.01)\end{array}$ & $\begin{array}{l}0.10 \\
(0.02)\end{array}$ & $\begin{array}{l}0.13 \\
(0.03)\end{array}$ & $\operatorname{tr}$ & $\begin{array}{l}0.01 \\
(0.001)\end{array}$ & $\begin{array}{l}0.01 \\
(0.003)\end{array}$ & $\begin{array}{l}0.96 \\
(0.05)\end{array}$ \\
\hline A-Kenia2 & $\begin{array}{l}0.04 \\
(0.01)\end{array}$ & $\begin{array}{l}0.13 \\
(0.01)\end{array}$ & $\operatorname{tr}$ & $\begin{array}{l}0.32 \\
(0.03)\end{array}$ & $\begin{array}{l}1.15 \\
(0.09)\end{array}$ & $\begin{array}{l}0.61 \\
(0.03)\end{array}$ & $\begin{array}{l}0.03 \\
(0.002)\end{array}$ & $\begin{array}{l}0.02 \\
(0.001)\end{array}$ & $\begin{array}{l}0.60 \\
(0.02)\end{array}$ & $\begin{array}{l}0.04 \\
(0.01)\end{array}$ & $\begin{array}{l}0.10 \\
(0.01)\end{array}$ & $\begin{array}{l}0.07 \\
(0.02)\end{array}$ & $\operatorname{tr}$ & $\begin{array}{l}0.01 \\
(0.001)\end{array}$ & $\begin{array}{l}0.01 \\
(0.001)\end{array}$ & $\begin{array}{l}0.81 \\
(0.04)\end{array}$ \\
\hline A-Kenia3 & $\begin{array}{l}0.01 \\
(0.01)\end{array}$ & $\begin{array}{l}0.14 \\
(0.01)\end{array}$ & $\operatorname{tr}$ & $\begin{array}{l}0.33 \\
(0.02)\end{array}$ & $\begin{array}{l}1.18 \\
(0.13)\end{array}$ & $\begin{array}{l}0.66 \\
(0.03)\end{array}$ & $\begin{array}{l}0.04 \\
(0.001)\end{array}$ & 0.02 & $\begin{array}{l}0.62 \\
(0.04)\end{array}$ & $\begin{array}{l}0.03 \\
(0.01)\end{array}$ & $\begin{array}{l}0.11 \\
(0.01)\end{array}$ & $\begin{array}{l}0.06 \\
(0.01)\end{array}$ & $\operatorname{tr}$ & $\begin{array}{l}0.01 \\
(0.002)\end{array}$ & $\begin{array}{l}0.01 \\
(0.001)\end{array}$ & $\begin{array}{l}0.79 \\
(0.03)\end{array}$ \\
\hline A-Mexico & $\begin{array}{l}0.02 \\
(0.003)\end{array}$ & $\begin{array}{l}0.12 \\
(0.01)\end{array}$ & $\operatorname{tr}$ & $\begin{array}{l}0.26 \\
(0.03)\end{array}$ & $\begin{array}{l}1.54 \\
(0.27)\end{array}$ & $\begin{array}{l}0.02 \\
(0.001)\end{array}$ & & ${ }_{j}^{\operatorname{tr}}$ & $\begin{array}{l}0.08 \\
(0.02)\end{array}$ & $\begin{array}{l}0.03 \\
(0.01)\end{array}$ & $\begin{array}{l}0.10 \\
(0.02)\end{array}$ & $\begin{array}{l}0.07 \\
(0.003)\end{array}$ & $\operatorname{tr}$ & $\operatorname{tr}$ & $\operatorname{tr}$ & $\begin{array}{l}0.99 \\
(0.07)\end{array}$ \\
\hline A-Peru1 & $\begin{array}{l}0.21 \\
(0.01)\end{array}$ & $\begin{array}{l}0.14 \\
(0.01)\end{array}$ & $\operatorname{tr}$ & $\begin{array}{l}0.49 \\
(0.01)\end{array}$ & $\begin{array}{l}1.62 \\
(0.10)\end{array}$ & 0. & $(0.002)$ & $\begin{array}{l}0.01 \\
(0.001)\end{array}$ & $\begin{array}{l}0.09 \\
(0.02)\end{array}$ & $\begin{array}{l}0.06 \\
(0.01)\end{array}$ & $\begin{array}{l}0.08 \\
(0.01)\end{array}$ & $\begin{array}{l}0.10 \\
(0.02)\end{array}$ & $\operatorname{tr}$ & $\operatorname{tr}$ & $\begin{array}{l}0.01 \\
(0.001)\end{array}$ & $\begin{array}{l}1.18 \\
(0.06)\end{array}$ \\
\hline A-Peru2 & $\begin{array}{l}0.10 \\
(0.01)\end{array}$ & $\begin{array}{l}0.16 \\
(0.01)\end{array}$ & $\operatorname{tr}$ & $\begin{array}{l}0.44 \\
(0.06)\end{array}$ & $(0.20)$ & $\begin{array}{l}0.02 \\
(0.017)\end{array}$ & $\begin{array}{l}0.02 \\
(0.004)\end{array}$ & $\begin{array}{l}0.02 \\
(0.004)\end{array}$ & $\begin{array}{l}0.09 \\
(0.043)\end{array}$ & $\begin{array}{l}0.06 \\
(0.004)\end{array}$ & $\begin{array}{l}0.08 \\
(0.03)\end{array}$ & $\begin{array}{l}0.10 \\
(0.03)\end{array}$ & $\operatorname{tr}$ & $\begin{array}{l}0.01 \\
(0.002)\end{array}$ & $\begin{array}{l}0.01 \\
(0.002)\end{array}$ & $\begin{array}{l}1.01 \\
(0.003)\end{array}$ \\
\hline C-Brasil & $\begin{array}{l}0.01 \\
(0.004)\end{array}$ & $\begin{array}{l}0.12 \\
(0.01)\end{array}$ & $\operatorname{tr}$ & 0.28 & $\begin{array}{l}1.54 \\
(0.50)\end{array}$ & $\begin{array}{l}0.02 \\
(0.03)\end{array}$ & $\begin{array}{l}0.03 \\
(0.02)\end{array}$ & $\begin{array}{l}0.02 \\
(0.03)\end{array}$ & $\begin{array}{l}0.06 \\
(0.01)\end{array}$ & $\begin{array}{l}0.02 \\
(0.01)\end{array}$ & $\begin{array}{l}0.05 \\
(0.001)\end{array}$ & $\begin{array}{l}0.05 \\
(0.02)\end{array}$ & $\operatorname{tr}$ & $\operatorname{tr}$ & $\operatorname{tr}$ & $\begin{array}{l}1.27 \\
(0.24)\end{array}$ \\
\hline
\end{tabular}




\begin{tabular}{|c|c|c|c|c|c|c|c|c|c|c|c|c|c|c|c|c|}
\hline \multirow[t]{2}{*}{ Code name } & \multicolumn{16}{|c|}{ Compounds } \\
\hline & 1 & 2 & 3 & 4 & 5 & 6 & 7 & 8 & 9 & 10 & 11 & 12 & & 14 & 15 & 16 \\
\hline R-Uganda1 & $\begin{array}{l}0.02 \\
(0.001)\end{array}$ & $\begin{array}{l}0.07 \\
(0.01)\end{array}$ & $\begin{array}{l}0.11 \\
(0.04)\end{array}$ & $\begin{array}{l}0.36 \\
(0.06)\end{array}$ & $\begin{array}{l}1.50 \\
(0.34)\end{array}$ & $\begin{array}{l}0.04 \\
(0.02)\end{array}$ & $\begin{array}{l}0.33 \\
(0.01)\end{array}$ & $\begin{array}{l}0.02 \\
(0.01)\end{array}$ & $\begin{array}{l}0.12 \\
(0.04)\end{array}$ & $\begin{array}{l}0.06 \\
(0.004)\end{array}$ & $\begin{array}{l}0.07 \\
(0.02)\end{array}$ & 0.08 & $\begin{array}{l}0.02 \\
(0.003)\end{array}$ & $\begin{array}{l}0.02 \\
(0.003)\end{array}$ & $\begin{array}{l}0.03 \\
(0.01)\end{array}$ & $\begin{array}{l}1.78 \\
(0.13)\end{array}$ \\
\hline R-Uganda2 & $\begin{array}{l}0.02 \\
(0.003)\end{array}$ & $\begin{array}{l}0.07 \\
(0.004)\end{array}$ & $\begin{array}{l}0.11 \\
(0.03)\end{array}$ & $\begin{array}{l}0.35 \\
(0.07)\end{array}$ & $\begin{array}{l}1.39 \\
(0.17)\end{array}$ & $\begin{array}{l}0.09 \\
(0.09)\end{array}$ & $\begin{array}{l}0.42 \\
(0.04)\end{array}$ & $\begin{array}{l}0.02 \\
(0.01)\end{array}$ & $\begin{array}{l}0.12 \\
(0.05)\end{array}$ & $\begin{array}{l}0.07 \\
(0.02)\end{array}$ & & $\begin{array}{l}0.10 \\
(0.01)\end{array}$ & $\begin{array}{l}0.02 \\
(0.002)\end{array}$ & $\begin{array}{l}0.01 \\
(0.003)\end{array}$ & $\begin{array}{l}0.03 \\
(0.01)\end{array}$ & $\begin{array}{l}1.84 \\
(0.20)\end{array}$ \\
\hline R-Vietnam1 & $\begin{array}{l}0.04 \\
(0.001)\end{array}$ & $\begin{array}{l}0.07 \\
(0.002)\end{array}$ & $\begin{array}{l}0.12 \\
(0.02)\end{array}$ & $\begin{array}{l}0.38 \\
(0.07)\end{array}$ & $\begin{array}{l}1.41 \\
(0.22)\end{array}$ & $\begin{array}{l}0.01 \\
(0.01)\end{array}$ & $\begin{array}{l}0.38 \\
(0.004)\end{array}$ & $\begin{array}{l}0.02 \\
(0.01)\end{array}$ & $\begin{array}{l}0.13 \\
(0.05)\end{array}$ & $\begin{array}{l}0.08 \\
(0.02)\end{array}$ & $\begin{array}{l}0.13 \\
(0.03)\end{array}$ & $\begin{array}{l}0.15 \\
(0.04)\end{array}$ & $\begin{array}{l}0.02 \\
(0.01)\end{array}$ & $\begin{array}{l}0.02 \\
(0.004)\end{array}$ & $\begin{array}{l}0.03 \\
(0.01)\end{array}$ & $\begin{array}{l}1.71 \\
(0.09)\end{array}$ \\
\hline R-Vietnam2 & $\begin{array}{l}0.05 \\
(0.01)\end{array}$ & $\begin{array}{l}0.08 \\
(0.01)\end{array}$ & $\begin{array}{l}0.12 \\
(0.02)\end{array}$ & $\begin{array}{l}0.40 \\
(0.03)\end{array}$ & $\begin{array}{l}1.52 \\
(0.23)\end{array}$ & $\begin{array}{l}0.03 \\
(0.03)\end{array}$ & $\begin{array}{l}0.39 \\
(0.04)\end{array}$ & $\begin{array}{l}0.02 \\
(0.004\end{array}$ & $\begin{array}{l}0.14 \\
(0.04)\end{array}$ & $\begin{array}{l}0.09 \\
(0.03)\end{array}$ & $\begin{array}{l}0.10 \\
(0.01)\end{array}$ & $\begin{array}{l}0.12 \\
(0.02)\end{array}$ & $\begin{array}{l}0.02 \\
(0.004)\end{array}$ & $\begin{array}{l}0.02 \\
(0.003)\end{array}$ & $\begin{array}{l}0.04 \\
(0.01)\end{array}$ & $\begin{array}{l}1.72 \\
(0.17)\end{array}$ \\
\hline
\end{tabular}

$1=$ Caffeic acid; $2=p$-coumaroyl quinic acid; $3=p$-coumaroyl- $N$-tryptophan; $4=$ chlorogenic acid $(3$ - $O$-caffeoylquinic acid); $5=$ neochlorogenic acid $(5$ $O$-caffeoylquinic acid); $6=$ cryptochlorogenic acid (4- $O$-caffeoylquinic acid); 7 = caffeoyl- $N$-tryptophan; $8=3$ - $O$-feruloylquinic acid; $9=5$ - $O$-feruloylquinic acid; $10=3,4-O$-dicaffeoylquinic acid; $11=3,5$ - $O$-dicaffeoylquinic acid; $12=4,5$ - $O$-dicaffeoylquinic acid; $13=3$ - $O$-feruloyl-4-caffeoylquinic acid; $14=3$ $O$-feruloyl-5-caffeoylquinic acid; $15=4$ - $O$-feruloyl-5-caffeoylquinic acid; $16=$ caffeine. Compouds below $0.01 \mathrm{~g} \mathrm{~kg}^{-1}$ are indicated as traces (tr). 
Table 2. List of Coffea arabica (arabica) and C. canephora (robusta) code names and country of origin.

\begin{tabular}{|c|c|c|c|c|}
\hline Code Name & Species & $\begin{array}{c}\text { Commercial } \\
\text { name }\end{array}$ & Cultivar & $\begin{array}{c}\text { Country of } \\
\text { Origin }\end{array}$ \\
\hline A-Brasil & C. arabica & Arabica & Arabica Natural & \\
\hline \multirow{3}{*}{ A-Colombia } & & & Terraforte & \\
\hline & C. arabica & Arabica & Colombia Excelso & \\
\hline & & & Raphael Lavato & \\
\hline A-Ethiopia & C. arabica & Arabica & Sidamo Grade 2 & \\
\hline A-Guatemala & C. arabica & Arabica & HB ep & Guatemala \\
\hline A-Honduras 1 & C. arabica & Arabica & HG ep "Marga & Honduras \\
\hline A-Honduras2 & C. arabica & Arabica & HG ep "Margay" & Honduras \\
\hline A-Honduras3 & C. arabica & Arabica & Catuahi,Caturra,Icatu & Honduras \\
\hline A-Honduras4 & C. arabica & Arabica & HG ep "Margay" & Honduras \\
\hline A-Honduras5 & C. arabica & Arabica & Catuahi,Caturra,Icatu & Honduras \\
\hline A-Kenya1 & C. arabica & Arabica & Arabica low grade & Kenya \\
\hline A-Kenya2 & C. arabica & Arabica & Arabica AK2 & Kenya \\
\hline A-Kenya3 & C. arabica & 310 & Arabica AK3 & Kenya \\
\hline A-Mexico & C. arabica & Arabica & PW ep & Mexico \\
\hline A-Peru 1 & атавыса & Arabica & Jacamar & Peru \\
\hline A-Peru 2 & C. arabica & Arabica & Tinamous & Peru \\
\hline C-Brasil & C. canephora & Caracol & Moka Fine Crop & Brasil \\
\hline R-Uganda1 & C. canephora & Robusta & Jolly Quartz & Uganda \\
\hline R-Uganda2 & C. canephora & Robusta & Jolly Quartz & Uganda \\
\hline & C. canephora & Robusta & Unwahed Vietnam & Vietnam \\
\hline R-Vietnam2 & C. canephora & Robusta & Clean Vietnam & Vietnam \\
\hline
\end{tabular}




\section{Legend for figures}

Figure 1. Structure formulae of the identified compounds extracted from Coffea arabica and Coffea canephora. 1 Caffeic acid; 2 p-coumaroyl quinic acid; 3 p-coumaroyl- $N$-tryptophan; 4 chlorogenic acid (3-O-caffeoylquinic acid); 5 neochlorogenic acid (5-O-caffeoylquinic acid); 6 cryptochlorogenic acid (4-O-caffeoylquinic acid); 7 caffeoyl- $N$-tryptophan; 8 3-O-feruloylquinic acid; 9 5- $O$-feruloylquinic acid; 10 3,4- $O$-dicaffeoylquinic acid; 11 3,5- $O$-dicaffeoylquinic acid; 12 4,5-O-dicaffeoylquinic acid; 13 3-O-feruloyl-4-caffeoylquinic acid; 14 3-O-feruloyl-5caffeoylquinic acid; 15 4-O-feruloyl-5-caffeoylquinic acid; 16 caffeine.<smiles>O=C(O)Cc1ccc(O)c(O)c1</smiles>

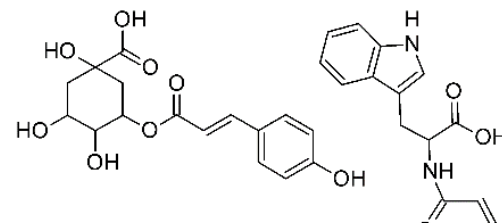

2<smiles>O=C(/C=C/c1ccc(O)c(O)c1)OC1CC([O-])(O)CC(O)C1O</smiles><smiles>O=C(/C=C/c1ccc(O)c(O)c1)OC(O)C1CC(O)C(O)CC1OC(=O)/C=C/c1ccc(O)c(O)c1</smiles><smiles>[CH]C=CCCCC</smiles><smiles>COc1cc(/C=C/C(=O)OC2CC(O)(C(=O)O)CC(O)C2O)ccc1O</smiles>

8<smiles>O=C(O)C1CC(O)C(O)C(O)C1CO</smiles>

11<smiles>COc1cc(C=CC(=O)OC2C(O)CC(O)C(O)C2OC(=O)C=Cc2ccc(O)c(O)c2)ccc1O</smiles><smiles>COc1cc(O)cc(/C=C/C(=O)OC2C(O)CC(O)(C(=O)O)CC2OC(=O)/C=C/c2ccc(O)c(O)c2)c1</smiles><smiles>COc1cc(/C=C/C(=O)OC2CC(O)(C(=O)O)CC(O)C2OC(=O)/C=C/c2ccc(O)c(O)c2)ccc1O</smiles>

14

12<smiles>C[C@H](/C=C/c1ccc(O)c(O)c1)NC(=O)[C@H](CC(=O)O)Cc1cccc2[nH]ccc12</smiles>

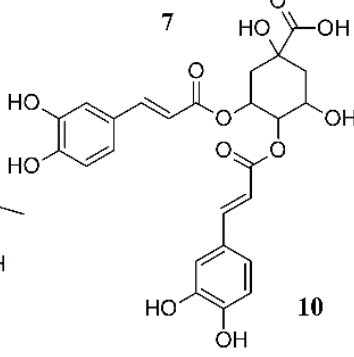<smiles>O=C(/C=C/c1ccc(O)c(O)c1)OC1C[C@](O)(C(=O)O)C[C@H](O)[C@H]1OC(=O)/C=C/c1ccc(O)c(O)c1</smiles><smiles></smiles>

16 
Figure 2. Distribution of total chlorogenic acids and caffeine (expressed as $\mathrm{g} \mathrm{kg}^{-1}$ of dry weight $\mathrm{g} / \mathrm{kg}$ ) from C. arabica and C. canephora of different geographical origin. C. canephora accessions show the highest content with respect to all other $C$. arabica accessions. See Table 2 for code names.

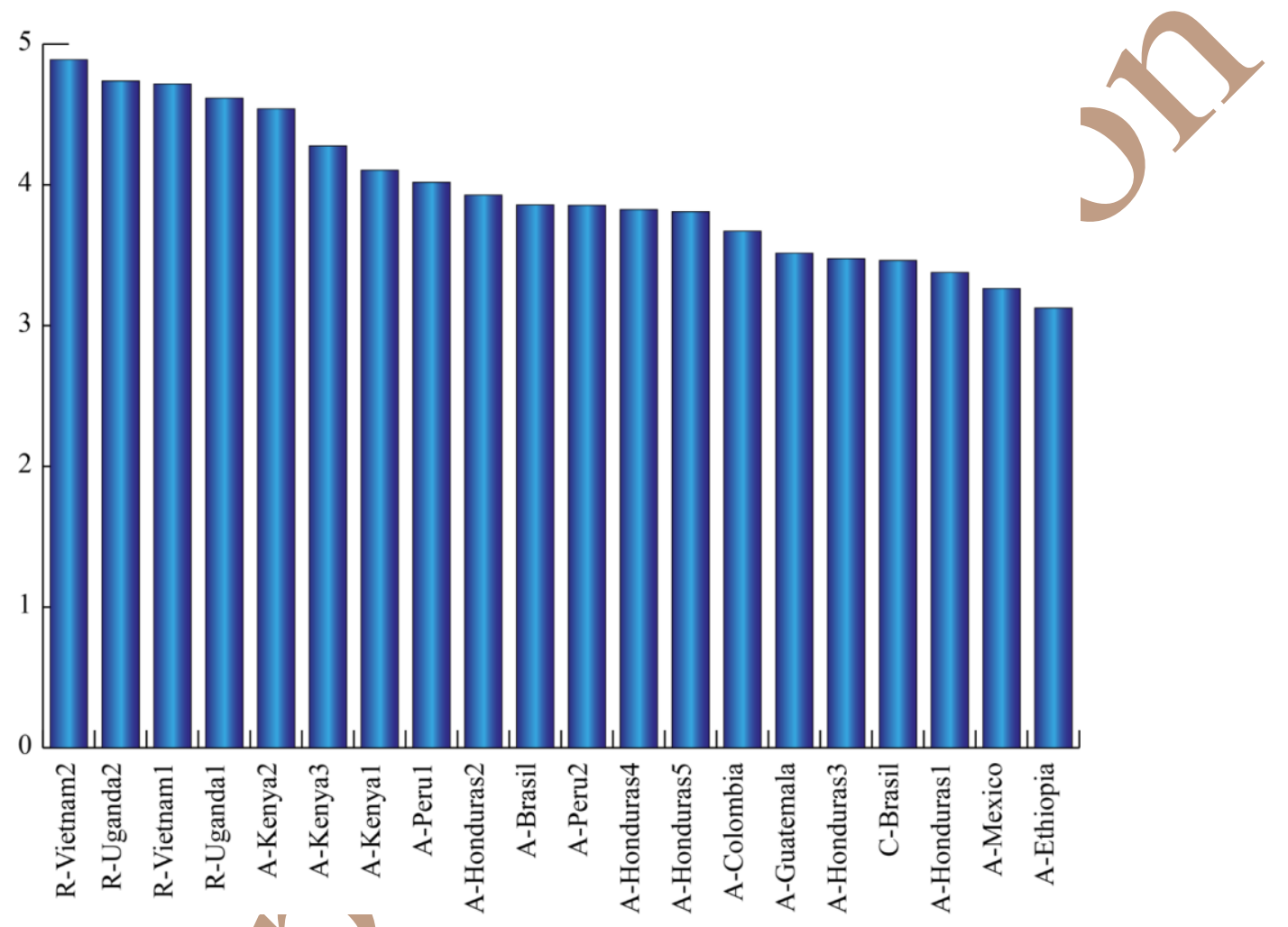


Figure 3. Scatter plot of total chlorogenic acids against caffeine content. A clear distinction is evident between $C$. canephora (R-Uganda and R-Vietnam) and $C$. arabica accessions. The $C$. arabica accessions from Kenya shows the highest content of chlorogenic acid and the lowest amount of caffeine. Metric bars indicate standard error; see Table 2 for code names.

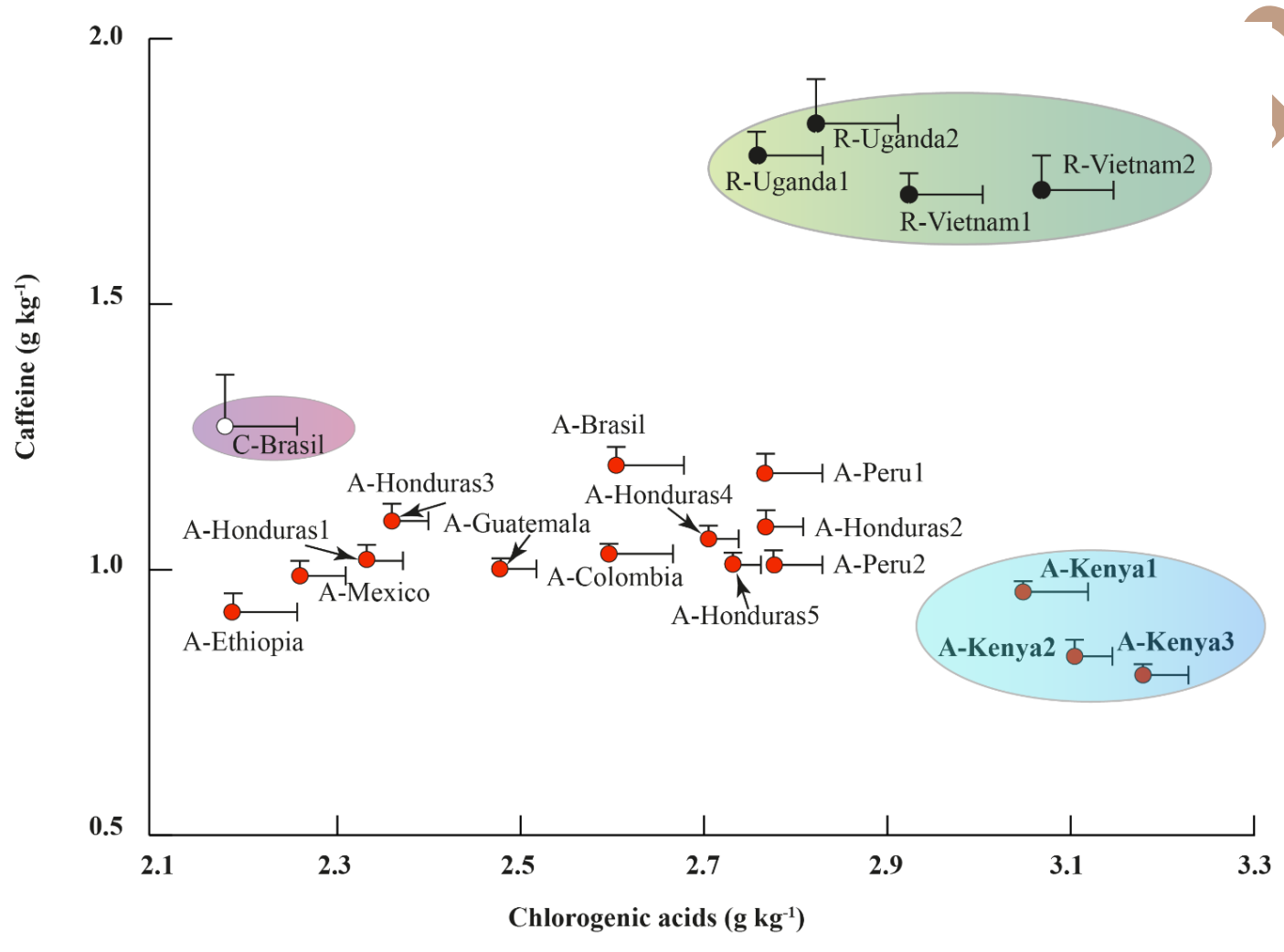


Figure 4. Scatter plot of the principal components analysis factor scores showing the separation of all C. canephora from $C$. arabica accessions. A clear separation is present inside the $C$. canephora group between Uganda, Vietnam and the "caracol" mutation from Brasil (C-Brasil). Among C. arabica accessions, accessions from Kenya show an opposite partition from all other varieties; see Table 2 for code names.

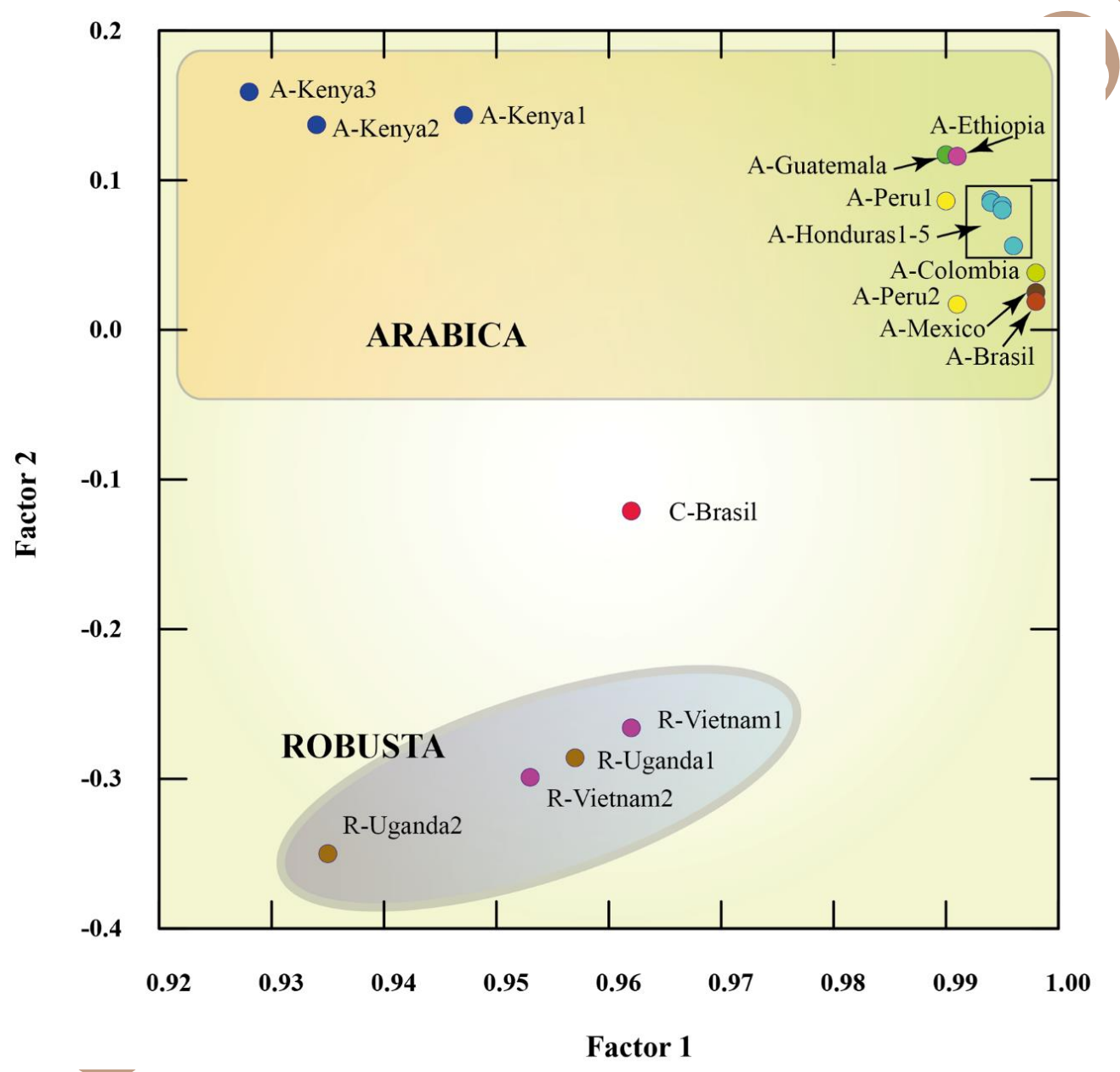


Figure 5. Scatter plot of the $\mathrm{IC}_{50}$ values from the reducing power and DPPH assays. The C. canephora accessions show the highest antioxidant capacity (lower $\mathrm{IC}_{50}$ values) than all other $C$. arabica accessions. Among $C$. arabica, the accessions from Kenya shows the highest antioxidant capacity. Metric bars indicate standard error; see Table 2 for code names.

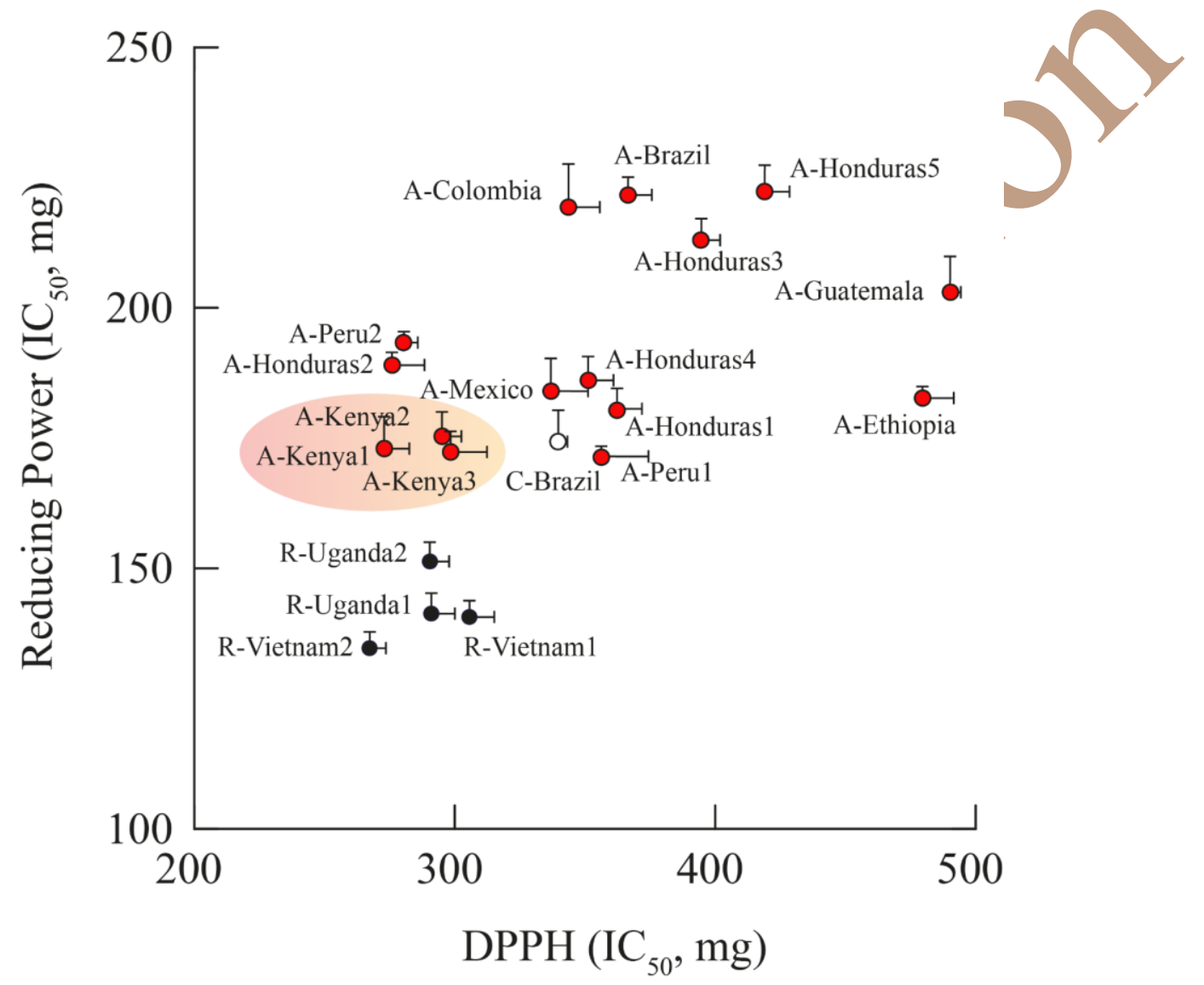

